\title{
Traditional Health Management vis-à-vis Rearing Practices Followed By the 'Black Bengal Goat' Farmers in Nadia District of West Bengal, India
}

\author{
Asif Mohammad $^{1 *}$ and Anupam Chatterjee ${ }^{2}$ \\ ${ }^{1}$ Eastern Regional Station, ICAR-National Dairy Research Institute, Kalyani, West Bengal, INDIA \\ ${ }^{2}$ Eastern Regional Station, ICAR- National Dairy Research Institute, Kalyani, West Bengal, INDIA \\ "Corresponding author: A Mohammad; E-mail:mail.asif.m@gmail.com
}

Received: 29 May, 2020

Revised: 03 Aug., 2020

Accepted: 20 Aug., 2020

\begin{abstract}
For securing the livelihood of the farmers, the role of small ruminant especially the goat are well established fact. The farmers of Nadia district of West Bengal, which is also the native tract of the Black Bengal goat, reared goats by following traditional practices. A study was conducted to find out the practices followed by the farmers for rearing goats in Nadia district. Data had been collected from 150 respondents belonged to three blocks of Nadia district in West Bengal state of India. Semi-structured interview schedule and PRA techniques were used to collect primary data. 'Effectiveness Index Scores' were calculated to identify the effectiveness of several traditional practices followed by the farmers for controlling ailments of Black Bengal goats. Majority of the activities pertaining to goat farming was performed by women farmers but in terms of ownership, the male dominance was observed. Farmers were following different traditional knowledge for curing and/or suppressing ailments of goats. Documentation of locally available plant's leaves, herbs or material for treating ailments like goat diarrhea, PPR, bloat, FMD etc., was done through the study and their effectiveness as perceived by the farmers were also analyzed. Farmers used to rear their animals in the close confinement of their own household. From the study it can be concluded that, the farmers of Nadia district were maintaining goats as a safeguard of financial insecurity and utilizing locally available ingredients effectively to cure common ailments of the goat.
\end{abstract}

\section{HIGHLIGHTS}

(0 Documentation and scrutiny for effectiveness as perceived by the farmers, to treat goat ailments by locally available resources.

0 Rationale of common practices followed by the goat farmers were analyzed

Keywords: Black Bengal goats, Effectiveness Index Score, Goat ailments, Traditional knowledge

Goats play significant role in securing livelihood of small, marginal and landless farmers. The domestic goat Capra hircus is an important livestock species in India and other developing countries (Joshi et al., 2004). Goats contribute significantly in farm households' total income as well as nutrition and food security of the family of goat keepers (Kumar et al., 2003). In major most part of the country goats are mainly reared for meat purpose. Besides meat, goats provide other products like milk, skin, fiber and manure (Kumar and Pant, 2003; Kumar, 2007). The Black Bengal goat is a famous goat breed in the world and is a very common breed of goat in Eastern and North Eastern part of India. It is well known for high fertility, adaptability, prolificacy fecundity and excellent skin quality (Hassan et al., 2007; Faruque et al., 2010; Islam et al., 2016). Black Bengal goat is mainly reared by the small holder farmers and women family members used to take care about the goats. These goats are reared in small flocks following partial or extensive grazing management system (Nandi et al., 2011). Farmers who are residing in the lower gangetic plains of West Bengal especially in Nadia district

How to cite this article: Mohammad, A. and Chatterjee, A. (2020) Traditional health management vis-à-vis rearing practices followed by the 'Black Bengal goat' farmers in Nadia district of West Bengal, India. J. Anim. Res., 10(5): 733-739.

Source of Support: None; Conflict of Interest: None क्) 
of West Bengal are heavily dependent on the rearing of goats. They used to follow various traditional knowledge in the routine management of goats. The role of traditional knowledge in agriculture as a whole and in livestock farming in particular is well acknowledged (Rao et al.,1995; Subrahmanyeswari and Chander, 2013). Farmers use to utilize indigenous knowledge to solve their problem in animal husbandry. Indigenous knowledge so developed is based on necessities, experimentation, curiosity and observation to mitigate the immediate situational problems (Talukdar et al., 2012). The study conducted by Nabukenya et al. (2014), demonstrated farmers have great wealth of knowledge in managing disease conditions of their livestock by utilizing plants and non-plants materials. The documentation of information pertaining to traditional wisdom of farmers in goat rearing through well designed scientific research and dissemination of such findings can enhance profitability of livestock farming. In the present study efforts has been made to document the traditional health care vis-à-vis rearing practices followed by the farmers in Black Bengal goat husbandry.

\section{MATERIALS AND METHODS}

\section{Location of the study area and selection of respondents}

The study was conducted in the Nadia district of West Bengal which is considered as the native tract of Black Bengal goats. As per the All India Coordinated Research Project on Goat Improvement, West Bengal has about 11.50 millions of Black Bengal goats with 621 no. of goats per 1000 households (pcgoatcirg.icar.gov.in). Primary data has been collected from the farmers of Nadia district, which is having large population of pure Black Bengal goats. The goat keepers of this district rear Black Bengal goats for generations together; as a result of that sufficient number of respondents was available. Blocks namely Chakdah, Haringhata and Ranghat-I has been selected randomly for collection of primary data. From each block 50 farmers who were involved in Black Bengal goat farming for last 20 years were selected randomly which made the total number of respondents/ informants to 150 for the study.

\section{Data collection}

A semi structured interview schedule was developed for collection of data. Some open ended questions were framed in the interview schedule to analyze the situation properly. Participatory Rural Appraisal (PRA) technique was utilized for identification and documentation of the traditional practices followed by the farmers for health management of goats. 'Effectiveness Index score' was calculated for measuring the effectiveness of each traditional practice followed by the farmers to repress and/ or curing ailments commonly occurring in the Black Bengal goats. Effectiveness Index of each traditional practice used for treating health ailment of Black Bengal goats was calculated by using the methodology of 'percentage mean score' calculation as described by Mohammad et al. (2017). The detailed formula is given as follows:

$$
E I S=\frac{(M E \times 3+E \times 2+L E \times 1)}{(T R \times 3)} \times 100
$$

Where, $E I S=$ Effectiveness Index Score

$M E=$ No. of respondent who feel the practice 'Most Effective'

$E=$ No. of respondent who feel the practice 'Effective'

$L E=$ No. of respondent who feel the practice 'Least Effective'

$T R=$ Total number of respondents

\section{RESULTS AND DISCUSSION}

\section{Ownership and role performance in management of Black Bengal goats}

From the table no 1 , it is evident that mainly women were taking care of goats, as in 128 households $(85.33 \%)$ women used to perform daily routine activities related with goat farming. Similar findings were reported by Dossa et al. (2008), Oladele and Monkhei (2008) and Jaitnera et al. (2001). In $57.33 \%$ of the household male members owned the right of goats and took major decision pertaining to goat rearing and marketing. From the study it was revealed that, in only 14.67 percent of the households, male members were playing the major role for goat farming and involved in daily management of goats. On the contrary, in 57.33 percent of household, the ownership of goat is with the male member of the house. It suggests 
that, though women were performing the major roles in goat rearing and devoting majority of their time in the goat husbandry but ownership in significant cases lying with the male members of the family. Webb and Mamabolo (2004) also reported that the major decisions regarding the goat farming were taken by the husbands. Male dominance in decision making resulted in the tilting of balance in favour of male members with respect to ownership right of goat.

\section{Rationale of Black Bengal goat husbandry as perceived by the farmers}

Black Bengal goat husbandry acts as regular source of income and liquid cash for the rural farmers. They used to rear female goats for kids. They used to sell male kids at high rates. Some farmers also purchase small male kids and sell them after one year which fetch them significant amount of profit. Goat rearing also helped the farmers during the period of emergency financial need. Majority $(87.33 \%)$ of the respondents reared Black Bengal goats for income generation purpose (Table 1). Though 14 (9.33\%) respondents reported that they reared the goats as the source of liquid cash during emergency financial needs. These livestock actually acted as source of liquid cash and gave the farmers financial support during the critical monetary situation. This suggests that, for sustainable livelihood security goats can be very useful for the small and marginal farmers. Tadesse et al. (2014), Bosman et al. (1997) also found that, income generation as the major purpose of keeping goats.
Traditional practices followed by the farmers in Black Bengal goat's health management vis-à-vis their effectiveness as perceived by the farmers

Some of the major ailments which are most commonly found in 'Black Bengal' goats vis-à-vis their traditional treatment followed by the farmers are reported in the table 2 along with 'Effectiveness Index Score'. Locally available tree plants, herbs, materials etc. were used by the farmers for controlling and/or treating several common goat aliments. Bloat, PPR, FMD, Diarrhea etc were treated by the farmers by using their traditional knowledge. The farmers also usually used several traditional practices to control endo and ecto parasite infestation, ticks and maggots in goats. Bloat of goat is a very common ailment found in Black Bengal Goat. Locally available ajowan / bishop's weed (Trachyspermum ammi), ginger (Zingiber officinale) and a pinch of salt mixture is fed to goat for treatment of bloat and the effectiveness of the treatment as perceived by the respondents was found to be as high as 90.44. Endo and ecto parasites were some of the major problems faced by the goat farmers and they were using traditional knowledge for controlling them and the farmers felt that traditional practice yielded good result which is evident from the fact that the 'Effectiveness Index Score' of practice was 87.33. Sometimes, farmers restrict goats for grazing to prevent ecto-parasite infestation. Similar type of recommendation was also made by Hassan et al. (2011). In the Peste des Petits Ruminants (PPR) disease sores were found in the mouth of goat and the farmers consider the disease as one of the serious ailments of goats

Table 1: ownership rights vis-à-vis rationale of Black Bengal goat rearing $(\mathrm{n}=150)$

\begin{tabular}{|c|c|c|c|c|}
\hline Domain & Parameters & Classification category & Frequency & Percentage \\
\hline \multirow{4}{*}{$\begin{array}{l}\text { Ownership and role } \\
\text { performance in management } \\
\text { of Black Bengal goats }\end{array}$} & Family members who performed & Male members & 22 & 14.67 \\
\hline & $\begin{array}{l}\text { major activities and devoted } \\
\text { maximum time in goat rearing }\end{array}$ & Female members & 128 & 85.33 \\
\hline & Ownership rights of goats & Male members & 86 & 57.33 \\
\hline & & Female members & 64 & 42.67 \\
\hline \multirow[t]{4}{*}{$\begin{array}{l}\text { Rationale of Black Bengal } \\
\text { Goat husbandry }\end{array}$} & Purpose of goat rearing & $\begin{array}{l}\text { Income generation by direct sale } \\
\text { of animal through-out the year }\end{array}$ & 131 & 87.33 \\
\hline & & Religious sacrifice purpose & 2 & 1.33 \\
\hline & & $\begin{array}{l}\text { Family consumption of goat } \\
\text { product (milk/ meat etc.) }\end{array}$ & 3 & 2.00 \\
\hline & & $\begin{array}{l}\text { Source of liquid cash during } \\
\text { emergency financial needs }\end{array}$ & 14 & 9.33 \\
\hline
\end{tabular}


Mohammad and Chatterjee

Table 2: Traditional practices followed vis-à-vis their effectiveness as perceived by the farmers in goat health management

\begin{tabular}{|c|c|c|}
\hline Ailment & Traditional practices followed & $\begin{array}{l}\text { Effectiveness } \\
\text { index score }\end{array}$ \\
\hline $\begin{array}{l}\text { Bloat of goat (except castrated } \\
\text { male) }\end{array}$ & $\begin{array}{l}50 \text { gm ajowan caraway/ bishop's weed (Trachyspermum ammi), } 5 \text { gm ginger } \\
\text { (Zingiber officinale) and a pinch of salt mixed together and one teaspoon of the } \\
\text { mixture is fed to goat }\end{array}$ & 90.44 \\
\hline Ecto parasite infestation & Ginger (Zingiber officinale) leaf paste used in whole body & 86.44 \\
\hline Endo and ecto parasite control & $\begin{array}{l}25 \text { gm turmeric (Curcuma longa) and } 5 \text { cloves of garlic (Allium sativum) are fed for } \\
4-5 \text { days }\end{array}$ & 87.33 \\
\hline Maggot & $\begin{array}{l}\text { Indian heliotrope/ local name- Hatisur (Heliotropium indicum) leave juice applied } \\
\text { locally }\end{array}$ & 92.89 \\
\hline Ticks & $\begin{array}{l}\text { Hill glory bower/ local name- Ghetu (Clerodendrum infortunatum) leave juice and } \\
\text { Crown flower/ Akanda (Calotropis gigantea) leave juice applied locally after tying } \\
\text { the face of goat }\end{array}$ & 86.44 \\
\hline $\begin{array}{l}\text { Peste des } \\
\text { Petits Ruminants (PPR) }\end{array}$ & $\begin{array}{l}10 \text { gm turmeric (Curcuma longa) and } 1 \text { clove garlic (Allium sativum) paste fed to the } \\
\text { animal }\end{array}$ & 86.22 \\
\hline $\begin{array}{l}\text { Peste des } \\
\text { Petits Ruminants (PPR) }\end{array}$ & $\begin{array}{l}\text { Borax is heated and popped up material is crushed and the dust is mixed with honey } \\
\text { and applied on the lesion/ sores }\end{array}$ & 77.33 \\
\hline Diarrhea & 4 teaspoon of tea leave (Camellia sinensis) is mixed with water and fed to goat & 85.11 \\
\hline Diarrhea & $100 \mathrm{ml} /$ day of whey is fed for $2-3$ days & 86.00 \\
\hline Diarrhea & $200 \mathrm{gm}$ bamboo leaves are fed to goats daily & 83.56 \\
\hline Foot-and-mouth disease (FMD) & $\begin{array}{l}250 \text { gm each of the following plants' leaves are taken: Mango (Mangifera indica)+ } \\
\text { Malabar plum/Black plum/ Jamun (Syzygium cumini) + Cotton tree/ local name- } \\
\text { Shimul (Bombax ceiba)+ Crown flower/ local name- Akanda (Calotropis gigantea) } \\
+ \text { Egyptian acacia/ local name- Babul (Vachellia nilotica). Then they are boiled } \\
\text { properly and strained. In warm condition the broth can be applied in the feet and } \\
\text { mouth for quick heal of wound. }\end{array}$ & 89.78 \\
\hline Foot-and-mouth disease (FMD) & $\begin{array}{l}\text { Borax is heated and popped up material is crushed and the dust is mixed with honey } \\
\text { and applied on the mouth lesion which can reduce wound }\end{array}$ & 85.33 \\
\hline Foot-and-mouth disease (FMD) & $\begin{array}{l}\text { Bel leaves (Aegle marmelos) juice reduce the wound and also reduce fly on the } \\
\text { wound }\end{array}$ & 85.56 \\
\hline Foot-and-mouth disease (FMD) & Washing wound with alum water $4-5$ times a day can reduce the impact of the disease & 72.44 \\
\hline Foot-and-mouth disease (FMD) & Mixture of 5 part Tar and 1 part Copper Sulphate $\left(\mathrm{CusO}_{4}\right)$ can reduce the wound & 87.11 \\
\hline
\end{tabular}

found in the region. Farmers used turmeric (Curcuma longa) and garlic (Allium sativum) or borax for treatment of the disease and consider the practice as very effective in controlling the disease. Farmers usually used locally available leaves of plants like Mango (Mangifera indica), Malabar plum/Black plum/ Jamun (Syzygium cumini), Cotton tree/ Shimul (Bombax ceiba), Crown flower/ Akanda (Calotropis gigantea), Egyptian acacia/ Babul (Vachellia nilotica) for preparation of broth to treat Footand-mouth disease (FMD). The farmers consider this traditional method can give good result which is evident from the fact that the practice got effectiveness index score of 89.78. In the remote areas where veterinary doctors were not easily available these treatments sometimes become lifesaver for goats. Moreover, all the materials/herbs used for the treatment of goats are locally available, low cost and gave good results in treatment of the ailments. For that reason, farmers used those herbs/ materials for treatment of goat ailments and passed on their traditional knowledge to next generation.

\section{Breeding aspects of Black Bengal goats}

On perusal of table 3 , it is revealed that, majority of the farmers (84\%) did not posses any breeding bucks. In the study area it was found that very limited number 
Table 3: Traditional rearing practices followed by the Black Bengal goat farmers $(n=150)$

\begin{tabular}{|c|c|c|c|c|}
\hline Domain & Parameters & Classification category & Frequency & Percentage \\
\hline \multirow[t]{6}{*}{ Breeding management } & \multirow[t]{3}{*}{ Mode of breeding } & By own breeding buck & 22 & 14.67 \\
\hline & & By breeding buck of other farmers & 126 & 84.00 \\
\hline & & Artificial Insemination of goats & 2 & 1.33 \\
\hline & \multirow[t]{3}{*}{ Preferred sex of born kids } & Male & 20 & 13.33 \\
\hline & & Female & 26 & 17.33 \\
\hline & & No preference & 104 & 69.33 \\
\hline \multirow[t]{8}{*}{ Housing system } & \multirow[t]{2}{*}{ Rearing system of goats } & Intensive & 26 & 17.33 \\
\hline & & Semi intensive & 124 & 82.67 \\
\hline & \multirow[t]{4}{*}{ Goat shed } & Separate goat shed & 40 & 26.67 \\
\hline & & Goats kept at cattle shed & 13 & 8.67 \\
\hline & & $\begin{array}{l}\text { Close confinement in farmers' house other } \\
\text { than living room of farmer }\end{array}$ & 94 & 62.67 \\
\hline & & Living room of farmers & 3 & 2.00 \\
\hline & \multirow{2}{*}{$\begin{array}{l}\text { Provide wind shield and } \\
\text { bedding material during } \\
\text { winter season }\end{array}$} & Yes & 136 & 90.67 \\
\hline & & No & 14 & 9.33 \\
\hline \multirow{9}{*}{$\begin{array}{l}\text { Nutritional management } \\
\text { of Black Bengal Goats } \\
\text { followed by the farmers }\end{array}$} & \multirow{3}{*}{ Feeding materials for goats } & Green grass and tree leaves & 6 & 4.00 \\
\hline & & Concentrates, tree leaves and green grass & 73 & 48.67 \\
\hline & & Paddy straw and Concentrates & 71 & 47.33 \\
\hline & \multirow[t]{2}{*}{ Providing water daily } & Yes & 150 & 100.00 \\
\hline & & No & 0 & 0.00 \\
\hline & \multirow{4}{*}{$\begin{array}{l}\text { Source of water provided to } \\
\text { the Black Bengal goats }\end{array}$} & Well & 12 & 8.00 \\
\hline & & Pond & 23 & 15.33 \\
\hline & & Tube well & 60 & 40.00 \\
\hline & & Tube well and pond & 55 & 36.67 \\
\hline
\end{tabular}

of respondents kept breeding bucks. Farmers who were rearing more than 10 animals used to keep breeding bucks. These bucks were kept by the owners for breeding purposes of their own animals but also for breeding of other farmer's doe on payment basis. During the informal discussion with the farmer it was revealed that generally ₹ $100 /$ - is being charged for per service. If the doe not become pregnant after the first service then the doe is again serviced free of cost after 15-21 days. The penetration of Artificial Insemination (AI) of goats in the study area was very less and only 1.33 percent of the respondents followed the technique for breeding purposes. Majority of the farmers $(69.33 \%)$ did not have any kind of preference in terms of sex of kids. The main reason of preferring female kids by the respondents was that, these kids can be used for increasing the flock size whereas; the male kids were preferred as the demand of male goats, especially the castrated male goats were very high for its meat quality. Though the frequency of respondents $(17.33 \%)$ who preferred the female kids was slightly high than the farmers $(13.33 \%)$ who preferred male goats, as they believed the female goats can generate sustainable income through their off-springs.

\section{Goat housing system maintained by the farmers}

Majority of the farmers $(82.67 \%)$ were rearing goats in semi intensive system. Due to poor financial condition, majority of the farmers could not afford the cost of intensive system and as a result of that they prefer semiintensive system of goat rearing. Jana et al. (2014) also reported from their study conducted at Burdwan district of West Bengal, that majority (90\%) farmers were rearing Black Bengal goats by following semi intensive system and the reason behind non-adoption of intensive system of rearing might be the initial high cost involvement and 
lack of knowledge about scientific goat rearing. Farmers followed open grazing for their animals during summer season for two hours in the morning and two hours in the evening. Around one fourth of the respondents (26.67\%) were having separate goat shed but 62.67 percent of the respondents reared their animals in the close confinement of their household; though 8.67 percent of the respondents kept Black Bengal goats at the cattle shed. Majority of the farmers were utilizing close confinement of their household for keeping their animals. As Black Bengal goats are generally sensitive to temperature fluctuation, hence their owner used to keep them in their household. Majority of the farmers were not having separate goat house. They were keeping their animals in separate arrangement due to lack of economic ability. This finding was in the line of Singh et al. (2010); Singh et al. (2013); Ekambaram et al. (2011). Overwhelming majority of the respondents $(90.67 \%)$ provided bedding material and wind shield during the harsh winter season and only 9.33 percent of the respondents could not arranged either separate bedding material or windshield or both, though they used other precautionary measures like tying old cloths or gunny bags around the animals during harsh winter season.

\section{Nutritional management of Black Bengal goats followed by the farmers}

Farmers used to take care of feeding of their goats seriously. In West Bengal the major crop produced is rice, for that reason the paddy straw was readily available to the farmers and they were using those straw as goat feed. Farmers were also feeding several tree leaves like mango, jackfruit banyan etc. along with other grasses like doob grass (Cynodon dactylon), Para grass (Brachiaria mutica), Napier grass (Pennisetum purpureum) etc. Only $4 \%$ of farmers could not afford feeding concentrate but majority of the farmers fed their animals with concentrate (Table 3). Concentrates, tree leaves and green grass was fed to animals by 48.67 percent of the Black Bengal goat farmers whereas, 47.33 percent of the respondents provided Paddy straw and Concentrates to their goats. All the farmers provided drinking water daily. The source of water provided to the animals was from well, pond, tube well and tubewell and pond both, though majority of the farmers (40.00 percent) provided water from tubewell to their goats. As tubewell was easily available in the study area, farmers used to give water to their animals from that source. Nandi et al., 2011 in their study also reported that, the major sources of water for Black Bengal goats were pond, well and tubewell.

\section{CONCLUSION}

Black Bengal goats which are indigenous to the state of West Bengal, India are kept by the farmers for economic motives and as a source of liquid cash. They rear these animals by investing very minimum amount (low input) and in return they get significant economic return (output). This goat breed is reared by farmers especially by the women member of the farm family by following traditional rearing practices. Black Bengal goats are very adaptive to the local climatic condition and with proper management practices can cushion the losses arise due to crop failure or reduction of price of other farm enterprises. Thus, rearing of Black Bengal goat can ensure sustainable livelihood of poor farm household and can also act as relatively safe farm business enterprise.

\section{REFERENCES}

All India Coordinated Research Project on Goat Improvement. Status of Black Bengal goat in West Bengal. Retrieved on January 9, 2020, from https://pcgoatcirg.icar.gov.in/black bengal_kolkata/pdf_download/Breed\%20Information.pdf

Bosman, H.G., Moll, H.A.J. and Udo, H.M.J. 1997. Measuring and interpreting the benefits of goat keeping in tropical farm systems. Agric. Sys., 53(4): 349-372.

Dossa, L.H., Rischkowsky, B., Birner, R. and Wollny, C. 2008 Socio-economic determinants of keeping goats and sheep by rural people in southern Benin. Agric. Hum. Values., 25: 581592.

Ekambaram, B., Gupta, B.R., Prakash, G.M.,Sudhaker, K. and Reddy, V.R. 2011. Housing, breeding and management practices of Mahabubnagar goats. Indian J. Anim. Sci., 81(8): 875-879

Faruque, S., Chowdhury, S.A., Siddiquee, N.U. and Afroz, M.A. 2010. Performance and genetic parameters of economically important traits of Black Bengal goat. J. Bangladesh Agril. Univ., 8(1): 67-78.

Hassan, M. M., Mahmud, S.M.N., Islam, S.K.M.A. and Miazi, O.F. 2007. A comparative study on reproductive performance and productivity of the Black Bengal and crossbred goat at Atrai, Bangladesh. Univ. J. Zool. Rajshahi Univ., 26: 55-57. 
Hassan,M.M., Hoque, M.A., Islam, S.K.M.A., Khan, S.A., Roy, K. and Banu, Q. 2011. A prevalence of parasites in Black Bengal goats in Chittagong, Bangladesh. Int. J. Livest. Prod., 2(4): 40-44.

Islam, F., Hossain, M.S., Sarker,S.C., Choudhury, M.P. and Majumder, A. 2016. Black Bengal goat keeping at Mymensingh Sadarupazila in Bangladesh. J. Biosci. Agric. Res., 6(02): 541-546.

Jaitnera, J., Sowe, J., Secka-Njie, E. and Dempfle, L. 2001. Ownership pattern and management practices of small ruminants in The Gambia - implications for a breeding programme. Small Rumin. Res., 40(2): 101-108.

Jana, C., Rahman, F.H., Mondal, S.K. and Singh, A.K. 2014. Management practices and perceived constraints in goat rearing in Burdwan district of West Bengal. Indian Res. $J$. Ext. Educ., 14(2): 107-110.

Joshi, M.B., Rout, P.K.,Mandal, A.K., Smith, C.T., Singh, L. and Thangaraj, K. 2004. Phylogeography and origin of Indian domestic goats. Mol. Biol. Evol.,21(3): 454-462.

Kumar, S. 2007. Commercial goat farming in India: an emerging agri-business opportunity. Agric. Econ. Res. Rev., 20: 503520.

Kumar, S. and Pant, K.P. 2003. Development perspective of goat rearing in India: Status, Issues and Strategies. Indian J. Agric. Econ., 58(4): 752-767.

Kumar, S., Vihan, V.S. and Deoghare, P.R. 2003. Economic implication of diseases in goats in India with reference to implementation of a health plan calendar. Small Ruminant Res., 47(2): 159-164.

Mohammad, A., Chatterjee, A., Bhakat, C., Dutta, S. and Dutta, T.K. 2017. Deciphering the status of willingness to pay for mobile SMS by different categories of farmers: a dairy farming perspective. J. Glob. Comm., 10(2): 79-83.

Nabukenya, I., Rubaire-Akiiki, C., Olila, D., Ikwap, K. and Höglund, J. 2014. Ethnopharmacological practices by livestock farmers in Uganda: Survey experiences from Mpigi and Gulu districts. J. Ethnobiol. Ethnomed., 10: 9.
Nandi, D., Roy, S., Bera, S., Kesh, S. and Kumar, S.A. 2011. The rearing system of Black Bengal goat and their farmers in West Bengal, India. Vet. World, 4(10): 254-257.

Oladele, O.I. and Monkhei, M. 2008. Gender ownership patterns of livestock in Botswana. Livest. Res. Rural Dev., 20(10): Article \# 156, Retrieved July 8, 2019, from http://www.lrrd. org/lrrd20/10/olad20156.htm

Rao, S.V.N., Van Den Ban, A.W., Rangnekar, D.V. and Ranganathan,K. 1995. Indigenous Technical Knowledge and Livestock. Handbook for Straw Feeding Systems, (Eds) Singh, K. and Schiere, J.B. ICAR, New Delhi, India, pp. 119128.

Singh, M.K., Dixit, A.K., Roy, A.K. and Singha, S.K. 2013. Goat rearing: a pathway for sustainable livelihood security in Bundelkhand region. Agric. Econ. Res. Rev., 26(Conference Number): 79-88.

Singh, M.K., Goel, A.K., Rai, B., Kumar, A. and Sharma, M.C. 2010. Impact of breed improvement programme on goat production under farmers flocks. Indian J. Anim. Sci., 80: 379-81.

Subrahmanyeswari, B. and Chander, M. 2013. Integrating indigenous knowledge of farmers for sustainable organic farming: An assessment in Uttarakhand state of India. Indian J. Tradit. Know., 12(2): 259-264.

Tadesse, D., Urge, M., Animut, G. and Mekasha, Y. 2014. Perceptions of households on purpose of keeping, trait preference, and production constraints for selected goat types in Ethiopia. Trop. Anim. Health. Prod., 46(2): 363-370.

Talukdar, R.K., Barman, S. and Hussain, A. 2012. Documentation and perceived rationale of Indigenous Technical Knowledge (ITK) utilized in Boro rice cultivation by farmers of Kamrup District of Assam. J. Acad. Indus. Res., 1(7): 412-418.

Webb, E.C. and Mamabolo, M.J. 2004. Production and reproduction characteristics of South African indigenous goats in communal farming systems. S. Afr. J. Anim. Sci., 34(Supplement 1): 236-239. 
